\title{
Imaginary Love in the Context of Emotional Consumption: A Levinasian perspective
}

\author{
Yi Qin \\ Renmin University, Beijing, China, yi.qin@ruc.edu.cn
}

\begin{abstract}
This article analyses love that emerges in dancing clubs, by integrating Emmanuel Levinas' ethics of face with sociological theories on emotional consumption. The seemly ideal appearance of a strip dancer with which a regular customer falls in love is not a true display of her authentic self, but rather a mask, which is a product of her emotional labor, sold to increase her income. The customer develops emotional ties with this fabricated persona and desires her love in return. In a commercial context, the customer often fails to recognize her complex subjectivity and to welcome her true otherness. He exploits her emotional labor, while she manipulates his emotions for money. His love, which is predicated on an imaginary foundation, cannot sustain outside of dance clubs. A "mask" and a Levinasian "face" may share the same physical body yet have distinct personalities, and can thus be confusing. Levinas' ethics calls for our immediate responsibility in the face of the Other. However, not all appearances of the Other are authentic. Sometimes it is even part of one's job to be disguised, such as in the case of strip dancers, actors, etc. It is vital to first identify and embrace the Other's true face before engaging in a relationship which requires mutual responsibility.
\end{abstract}

KEYWORDS: face, mask, emotional labor, emotional consumption, Levinas

\section{Introduction}

Sociologist Arlie Russell Hochschild brought up the concept of "emotional labor" in her 1981 book The Managed Heart: Commercialization of Human Feeling. She defines emotional labor as a form of feeling or emotion management "to create a publicly observable facial and bodily display," and this labor is "sold for a wage" (Hochschild 1981, 7). This article analyses clubs where female dancers perform lap dances, which involve erotically grinding on a male customer's lap either topless or fully nude. Customers are required to keep their hands off the dancer's body during the performance. Payments are directly given to dancers, who pay about $15-20 \%$ of their income to club owners (Egan 2005, 105). In an exotic dance club, apart from dancing, dancers need to show a desirable attitude in order to make their clients feel good. This kind of emotional labor can be tiring, yet it is indispensable to attract and to maintain a clientele to ensure a stable income. Attracted by a certain dancer, some customers may come to see her performance regularly and frequently, and may even develop romantic sentiments towards her. He would want to see her outside of the club, but a dancer rarely agrees (Egan 2005, 97). When falling in love with an exotic dancer, the customer actually dedicates his own emotions to the object that he consumes. She then replies with feigned emotions through emotional labor. Thence emerges an affective relation between the consumer and the service provider, or what we call "emotional consumption" (Egan 2005, 91).

French philosopher Emmanuel Levinas' ethics about face and the Other was developed under the background of World War II. The unprecedented crisis facing the human race made him rethink the western tradition of totalitarianism, which emphasizes uniformity (Arendt 1976, 755). The totalitarian logic encourages people to assimilate the Other and to eliminate differences. Levinas, on the contrary, proposes welcoming and embracing the Other in interpersonal encounters. In this article, I will analyze the sentimental connections between dancers and their regulars, discuss the reasons why their relations cannot sustain, and point out a few limitations of Levinas' theory in explaining interpersonal relationships.

\section{Same face, different visages}

For Levinas, the French word visage means the way in which the Other presents himself, beyond the idea of the Other in me (Lévinas 1971, 41). A visage "brings a notion of truth which is not the unveiling of an impersonal Neutral, but an expression" (Lévinas 1971, 41). When we encounter someone face-to- 
face, the first question that we ask ourselves, should not be an epistemological one about how to get to know and understand the Other, but rather an ethical one, the one about how to treat the Other. In fact, the absolute otherness of the Other lies beyond our cognition, and can never be fully grasped. However, is it possible to consider the how question, before knowing some basics about the what question?

In most circumstances, we can tell another person's feelings by looking at his or her facial expressions. We can tell that a waitress is being arrogant towards a customer from her scornful looks. If a waitress controls her temper and puts on a polite smile when dealing with a demanding customer, we know that she makes an effort to perform emotional labor. We would praise her for being professional. In some other situations, however, an observer may fail to notice traces of emotional labor. For example, very skillful actors can lure the audience into believing that he is not acting, but is really being himself in a movie. Children sometimes may even become angry when they meet an actor who once played a bad guy in a TV series that they saw if they mistake the person in real life for the character he played on TV. If we consider the fictitious world in the movie as an independent world, the corporeal face of an actor represents the visage of a character within the movie. Characters are fictitious for the audience outside the movie-world but are real vis-à-vis each other in the movie-world itself. The role in the movie-world and the person in the real world share the same bodily face, but everything behind it is different. When interpreting the fictitious character, the actor lent his corporeal face to this character. It's almost like creating a twin, who has distinct experiences, culture, habits, etc. Two visages, although not at the same time, are incarnated in the same face, one from the made-up world, one from the real world. To distinguish a visage result from emotional labor from authentic visages, we can name the former "mask visage". Normally, adult audience is aware that there is a fourth wall which separates the two worlds, and won't confuse the role with the actor himself as children might do. A fourth wall is an "imaginary wall the audience looks through to hear and to see events" (Bell 2008, 37).

In an exotic dance club, dancers' performance includes both dances as well as emotional services. The countenance that they display does not necessarily represent what they really think or how they really feel about a customer. Their job, like other performing arts, requires them to embody a different personality. At work, a dancer's mask visage represents a made-up persona that only exists in the club, which is designed to accommodate their customers' needs for an ideal female personage. If a waitress who controls her temper at work is considered professional, an exotic dancer who plays the role of a sexy and sweet girl also performs her job duties, thus is also professional. As a product of her emotional labor, her mask visage is objectified and is alienated from herself in a Marxist sense.

Unlike in front of a silver screen or in a theater, settings of exotic dance clubs deliberately allow performers to have direct physical contacts with their clients. Physical boundaries between the dancers and the clients are almost non-existent, as dancers can use various body parts to grind against the customers' body. In addition, one-to-one conversations facilitate emotional exchange and help create an atmosphere of intimacy. As a result, the fourth wall that separates the performers from the audience is not as obvious as in a theater, the boundary line is more obscure. Some men may forget that the dancer on their laps is actually in a different world separated by the fourth wall, despite the fact that they are physically touched. What truly connects her emotional labor with a customer is not their physical contacts nor their emotional bonds, but rather an exchange of labor and money. The social relations between them, as a matter of fact, are "material relations between persons and social relations between things" (Marx 2008, 47). If a customer falls in love with a mask visage without noticing the commodified context and figuring out what's behind the mask, his story is doomed to tragedy.

It is worth mentioning that the settings in an exotic dance club are very different from the Parisian striptease clubs described by Roland Barthes in his book Mythologies. Unlike lap dance, French striptease has been given a "pent-bourgeois status". It is performed on stage fair and square, such as in Moulin Rouge. It is a type of honorable sports which is entitled to "rejoin the world of the public." Performers can pursue a career in this field and are "socially situated." Even the dance itself is "in no way an erotic element", but rather a "last barrier consisting of ritual gestures which 
have been seen a thousand times". The dance "acts on movements as a cosmetic", and actually "hides nudity" (Barthes 1957, 137-140). In contrast, an exotic dance club remains a place restricted for intimate lap dances that are intended to be titillating.

\section{Imaginary love towards mask visages}

Sociologist R. Danielle Egan once conducted a participant observation in an exotic dance club while working as a dancer there. She noticed that exotic dancers exerted more emotional efforts to keep their regular customers compared to other customers. For instance, she would frequently discuss daily life and work problems with regulars in the intervals of erotic dances (Egan 2005, 88). Her kind words and friendly attitude make him feel that he is attractive and unique. He gets the impression that he is "worth being listened to regardless of the money that he pays" (Egan 2003, 94), and that she provides him something that he cannot get elsewhere (Egan 2003, 117). We may wonder, do dancers really enjoy their relationships with their regulars? This is something that regulars are also eager to know. In an interview with the sociologist, one dancer admitted that sometimes she really enjoys the conversations, while sometimes she just shakes her head and smiles. She said, "What the hell I am going to do, tell them they are assholes?" (Egan 2005, 101). In another article discussing relationships between strip dancers and their regulars, the author noticed that some dancers may be excited when seeing a regular, and prefers to stay with him in the VIP room than messing with the crowd (Frank 1998, 183). Whether they really enjoy it or not, dancers at least always act as if they do. They are well aware that the customers want the "real thing" or, to put it differently, they long for the authenticity of the dancers' emotions. In response to this customer demand, dancers even developed a set of strategies of professional interactions in the club (Rambo and Ellis 1989, 217). They offer customers "feigned authenticity" to make them believe that they are true to them (Egan 2005, 89).

How do we understand the emotions that regulars develop for a certain dancer? Regulars themselves describe their feelings for their beloved dancers as "real" emotions, and "thus they were in 'relationships' as opposed to commodified exchanges." Yet they are still worried about whether they are nothing more than "a customer" for the dancer (Egan 2005, 98). They "want love in an impossible context, and return repeatedly to a scene that will always cause them pain". Therefore, it seems plausible that these regulars are masochists, as Egan points out in her article (Egan 2005, 93). I would argue, however, that regulars are not masochist because they do not enjoy being in pain in their relationships. Masochist, as defined in the Merriam-Webster dictionary, is "a person who derives sexual gratification from being subjected to physical pain or humiliation," or "a person who takes pleasure in pain and suffering" (Merriam-Webster 2019). Admittedly, regulars do feel pain when they cannot be certain about the authenticity of their beloved dancer. But they in no way take pleasure in it. On the contrary, all that they are looking for are signs of hope, gestures that indicate that they can aspire a happy life with their favorite dancer. They keep coming back to seek confirmations, not torture. They long to be saved from uncertainty. In order to keep a stable resource of income, dancers keep offering regulars what they need by pretending that they are really interested in him. Although dancers refuse to go on a date with their regulars, they may go as far as giving him a cell phone number, and spend time doing "customer-relationship management" over the phone outside of their working hours (Egan 2005, 102). Regulars always continuously demand more to further test dancers' authenticity, for instance, by threatening her to "stop coming to the club altogether if dancers do not see them outside the club" (Egan 2005, 102). "Reassurance is a ritualized interaction that takes places constantly in the relations between regular and dancer" (Egan $2005,102)$. If the demand becomes too much to handle, the dancer will eventually opt to abandon the regular. Then the regular would move to another dancer or really leaves the club for good (Egan $2005,102)$. Without a masochist tendency, he doesn't come back eternally for the purpose of being hurt, he comes back only to reassure that he is being loved. Because of that, regulars are different from masochists.

From a Marxist perspective, the regular's love is a kind of commodity fetishism, which outlines social relations in commodified contexts as relationships between commodity and money 
as opposed to real interpersonal relationships (Marx 2008, 50). Regular is observed to fetishize the commodified mask visage produced by dancer's emotional labor (Egan 2005, 88). Along with the fetishization of dancer's emotional labor comes the commodification and fetishization of the subject. "In paying money, men are not only buying a commodity but putting themselves into the commodity too". Exotic dance club offers consumers a setting dissimilar from mundane life. Therein they are permitted to behave differently than in their daily lives. Customers are "paying to become one other," and "seeks to be relieved of his everyday persona (Allison 2009, 21). Therefore, commodification and fetishization happen on both dancers and customers.

Besides the fact that dancer's mask visage appears attractive, a regular customer also projects his subjective imagination upon this figure. He fantasizes her as sexy, feminine, agreeable, sweet, empathetic, etc. This is the image of a typical ideal partner in a phallocentric masculine culture. On the one hand, regular's object of love is an unreal mask visage; on the other hand, this mask visage is further idealized with his own imagination. I would call this mirage-like love "imaginary love." The term "imaginary love" comes from Xavier Dolan's 2010 movie Les Amours Imaginares, whose official English translation is Heartbeats. Jacques Lacan explained love as an imaginary passion: the beloved is not a real other but is something created out of one's own figure. In his own words, "I love you, but, because inexplicably I love you in something more than you-the object petit a-I mutilate you" (Lacan 2004, 267, italic in the original). The object petit a, or small a, differentiates the object from Autre (Other) or grand Autre (big Other) (Lacan 2004, 282). It is not the self of the Other, but something else. And the gap between the two can never be crossed (Lacan 2004, 270). Furthermore, the imagined other is, in fact, an idealized self. Hence, this love is narcissistic. Additionally, the person who loves does not only love the idealized figure but also desires a return of love. Therefore, this love is autoerotic (Demandante 2014, 109), viz. the person wants to be a loveable object of that idealized self. What regulars mean by "I love you" is "I want you to love me" (Egan 2005, 97). Through language, his love is transformed into "a demand for love" (Demandante 2014, 111).

Regulars' feelings for the dancers share certain characteristics with what Levinas calls "metaphysical desire." Metaphysical desire is a desire for something beyond all that can simply fill it (Lévinas 1971, 22). It goes "towards something else entirely, towards the absolute other" (Lévinas 1971, 21). Regulars think they can start a good life together with a dancer, while the true person behind the mask visage is unknown to them. The emerged desire is one-directional since dancers actually don't want to go on a date with a customer. They come up with various reasons to decline invitations to meet outside of the club (Egan 2005, 102). As Levinas points out, love, in general, is "considered as the satisfaction of a sublime huger," if this is possible, "it is because most of our desires are not pure and neither is the love" (Lévinas 1971, 22)

Despite the above-mentioned similarities with metaphysical desire, his desire is rather what Levinas would call a "need". Levinas distinguished the metaphysical desire and need in his book Totality and Infinity: "In need, I can bite the real and satisfy myself by assimilating the other. In Desire, there's no bite into being, no satiety" (Lévinas 1971, 21). In other words, need has a concrete object, as while the object of metaphysical desire is untouchable. A regular customer desires a dancer, both her body and her love. The customer is not likely to grasp the absolute otherness of the dancer, yet ideally, he would like to be able to permeate into the dancer, assimilate her into his own life. Therefore, it is fair to say that his love is a need in a Levinasian sense.

As Levinas wrote, when somebody needs something, he or she "convert(s) this other into the same by labor" (Lévinas 1971, 121). The customer's need pushes him to attempt to take her into his own life. In search of happiness, he continuously goes back to the club to fill his need like filling a void. For Levinas, happiness is "not made up of an absence of needs, but of the satisfaction of all the needs" (Lévinas 1971, 119). Unlike desire, "need is susceptible to satisfaction" (Lévinas 1971, 118), viz. needs can be satisfied, but desire cannot be so. Dancers know very well how to make customers feel happy. They simply offer him carefully feigned authenticity to fulfill his needs, just like the way people satisfy those who are hungry with a lot of food. Corey Beals mentioned that 
Levinas' notion of love is to divide it into "desire" and "need" (Beals 2007, 3). In a stricter sense, if the regular's needs are fillable by concrete things, they are neither a pure desire nor pure love.

\section{Assimilation of mask visage: a destined failure}

As discussed earlier, the customer's love is based on need. This love is "eros" ("̌p $\omega \varsigma)$, not "agape" ( $\dot{\alpha} \gamma \alpha \dot{\pi} \eta)$. For Levinas, the latter is unconditional, while the former is "cruel, egoistic, and lustful" (Casey 2010, 23). In addition, eros has a unifying power and is accountable for "bringing together things, individuals and entities" (Demandante 2014, 105). This explains why a regular, motived by eros, is not satisfied with mere imaginations. Instead, he wants to realize his fantasies in real life. Levinas acknowledged that "labor" is necessary when someone converts the beloved other into oneself (Lévinas 1971, 121). When a customer becomes attached to a dancer, he persists in asking her out, and constantly makes an effort to make his wish come true.

The regular thinks that the dancer can accept everything about him in daily life, just like how she tolerant she is in the dance club. However, her tolerance is part of her mask visage at work. On the other hand, the customer wouldn't be able to accept every aspect of her in real life neither. As a dancer comments, "they think I look like this all the time. If they saw me in the morning before a cigarette and coffee, trust me, things would change" (Egan 2005, 101). Her mask visage hides too many sides of her subjectivity that the customer has no clue about. Outside of the lieu of commodity exchange, the dancer, like any other person, would have her own demands waiting to be fulfilled by her partner. She would become a demanding wife, just like the regular's wife that he often complains about. His willingness to be together with the dancer would eventually diminish if she were to show him her authentic visage.

Limited to the context of commodity exchange, a regular can only interpret the dancer using traces of her mask visage at work. However, this is not enough to fully understand someone. "If we try to understand someone from his work, he more overheard than understood. His life and his work mask him" (Lévinas 1971, 194). Who someone is cannot be represented by what someone is (professionally, for example) (Lévinas 1971, 193). Everything related to the dancer's professional life hides who the person really is. The physique of her sexy female body itself already constitutes a basic sign, as Roland Barthes would put it (Barthes 1957, 16), and signs need to be interpreted (Lévinas 1971, 194). Unlike in uncommodified contexts, the fact that a woman who is performing erotic dances in a club openly displays her nicely sculpted body doesn't mean that she has sexual interests in her clients. This is a sign of a deliberately designed commodity but not of any true intentions. As we can see, both her physical and emotional masks hinder the customer to fully understand who she really is. Under this circumstance, in a Hegelian sense, the regular would not be able to recognize (anerkennen) and to love the dancer's complexity and multiple identities (Iser 2013).

As mentioned earlier, regular's love is a demand of love. Levinas sees nothing wrong in wanting one's beloved to love him or her in return. Not only it is normal, but one loves fully "only if others love me". He further explains that this is "not because I need the recognition of Others, but because my voluptuosity is delighted by his voluptuosity" (Lévinas 1971, 298). What is problematic is not his demand, but rather his ignorance of the complexity of the dancer's visage. The faked visage says "I'm fond of you"; while the authentic one is not able to offer any return of love. The regular look for love in someone who acts as if she loves him, but doesn't really love him. His pursuit is destined to fail.

It is noticeable that normal couples can also experience attitude and behavior changes in a relationship. People tend to show a better image of themselves when they first start dating. As time goes by and the relationship stabilizes, they would become more relaxed, and start to unveil their true self. It's common to experience disappointment when the other is no longer as nice as before. The process is rather gradual among couples who do not find themselves in a commodified condition, and it happens rather naturally. In comparison, the rupture between a dancer's mask visage and authentic visage would happen in a more sudden manner, if they go out of the 
commodified context. It is like abruptly flicking a card with two sides. Therefore, even if he were to get a chance to date a dancer in real life, his love would unlikely to survive the sudden shock.

\section{Discussions and conclusions}

In daily interactions, authenticity, meaning being open to him or herself and being transparent to other persons, is "a precondition to enter dialogue" (Schmid 2001, 271). Danish philosopher Søren Kierkegaard wrote in his book Either/Or, "The great is not to be this or that, but to be oneself - this can every man do, when he wants it" (Kierkegaard 1843, 184). Nevertheless, there are countless reasons why people hide his or her genuine self. For example, some feel vulnerable when exposing themselves to others, and prefer to avoid potential criticism; others are not confident enough to fully accept him or her true self. In the case of exotic dancers, they manage their true feelings through emotional labor to receive economic compensation.

Customers pay for the dancers' emotional labor, and they do enjoy being well treated by nice girls like the dancers. "If jouissance is the very eddy of the Same, it is not ignorance of the other, but its exploitation" (Lévinas 1971, 119). In this sense, the customer exploits the dancer for his own pleasure. On the other hand, the dancers purposely continue to fake and to keep him hooked in order to maintain the regular's attachment to her. His efforts to pursue an ideal lover, as well as his emotions, are all manipulated by the dancer to earn more money from him. Therefore, the dancers are also exploiting the regulars. Exploitation goes both ways.

Although the persona that the customer embodies when he comes into an exotic dance club is not totally the same as how he is in everyday life, the psychological elation and the pain that he feels are claimed to be real (Egan 2005, 98). He might be disguised in some aspects, but his emotions remain genuine. It is like a situation in which someone goes to a party undisguised, only to find out that it is, in fact, a masquerade where everybody else wears a mask. The customer is emotionally hurt when the relationship with his favorite dancer fails, but she isn't, as she did not build any authentic feeling as he did.

According to Levinas, I should welcome the visage of the other, and "expose myself to the interrogation of the Other". "And this urgency of the response, acuteness of the present, engenders me for responsibility" (Lévinas 1971, 194). Before assuming responsibility, however, it is desirable to first unravel what one is facing. Levinas didn't distinguish mask visage and authentic visage, nor did he discuss their respective relationships with the corporeal body. As shown in the case of regulars' imaginary love, the epistemological question about whom we are dealing with remains nevertheless important when entering into an interpersonal relation. Otherwise, one might suffer unwanted surprises as the mask visage of the other fades away and the authentic visage appears. Disappointed by the reality, one might fail to continue to carry out the responsibility that one previously undertook.

Levinas' ethics focuses on intersubjective relations (Bergo 2017), while strictly speaking, the relationship between a lap dancer and a regular customer doesn't fall into this category. In their relationship, the dancer's subjectivity is hidden and disguised; the customer as a subject is also fetishized and is different from everyday life. In our daily encounters, how often is subjectivity fully exposed without being hidden or repressed? In professional contexts, for example, it is not uncommon to put emotional efforts into one's work, even in situations where there is no immediate monetary reward. For instance, a teacher often experiences situations where he or she needs to restrain anger or other emotions when facing his or her students. It's simple yet difficult to be oneself, otherwise, it wouldn't be considered "great" as Kierkegaard pointed out. The extent to which subjectivity is exposed in daily encounters thus sets limitations for the application of Levinasian ethics.

Further research questions can be investigated to elaborate on related issues. For instance, whether showing one's authentic visage in all circumstances should be a Kantian categorical imperative? If so, it would save many efforts in interpersonal communications, as we would no longer need to distinguish counterfeits from the authentic. But what about professions which require emotional labor? Without disguising one's authentic visage, performing arts would be impossible. 
Also, if people all let out their emotions freely without any self-control, without anything to "bridle men's ambition, avarice, anger, and other passions," our society might consequently fall back into the state of nature, or a war of "everyone against everyone", as Thomas Hobbes described in Leviathan (Hobbes 1997, 103). If being oneself is not a widely applicable rule in society, then questions such as when we should put on what kind of visage, how to distinguish mask and authentic visages, when we can start to assume responsibilities towards others, etc., are all examples of topics worthy of being studied.

\section{References}

Allison, Anne. 2009. Nightwork: Sexuality, Pleasure, and Corporate Masculinity in a Tokyo Hostess Club. University of Chicago Press.

Arendt, Hannah. 1976. The Origins of Totalitarianism. Boston: Houghton Mifflin Harcourt.

Barthes, Roland. 1957. Mythologies.Paris: Éditions du Seuil.

Beals, Corey. 2007. Levinas and the Wisdom of Love: The Question of Invisibility. Baylor University Press.

Bell, Elizabeth. 2008. Theories of Performance. Los Angeles: SAGE.

Bergo, Bettina. 2017. "Emmanuel Levinas." The Stanford Encyclopedia of Philosophy (Fall 2017 Edition), Zalta, Edward N. (ed.). Accessed March 10, 2019. https://plato.stanford.edu/archives/fall2017/entries/levinas/.

Casey, Thomas G. 2010. "Kierkegaard and Levinas on More Perfect Human Love." Irish Theological Quarterly 75(1): $15-28$.

Demandante, Darlene. 2014. "Lacanian Perspectives on Love.” Kritike, June: 102-118.

Egan, R. Danielle. 2005. "Emotional Consumption: Mapping Love and Masochism in an Exotic Dance Club." Body \& Society 87-108.

Egan, R. Danielle. 2003. 'I'll Be Your Fantasy Girl, If You'll Be My Money Man: Mapping Desire, Fantasy and Power in an Exotic Dance Club." Journal of Psychoanalysis, Culture and Society 8(1): 109-20.

Frank, Katherine. 1998. "The Production of Identity and the Negotiation of Intimacy in a 'Gentleman's Club'." Sexualities 1(2): 175-201.

Hochschild, Arlie Russell. 1981. The Managed Heart: Commercialization of Human Feeling. Berkeley: University of California Press.

Hobbes, Thomas. 1997. Leviathan: Or the Matter, Forme, and Power of a Commonwealth Ecclesiasticall and Civil. Atria Books.

Iser, Mattias. 2013. "Recognition." The Stanford Encyclopedia of Philosophy (Fall 2013 Edition). Accessed December 22, 2018.

Kierkegaard, Søren. 1843. Enten - Eller. Kjøbenhavn: C.A. Reit.

Lacan, Jacques. 2004. The Four Fundamental Concepts of Psycho-Analysis. Karnac Books.

Lévinas, Emmanuel. 1971. Totalité et Infini - Essai sur L'Extériorité. Martinus Nijhoff.

Marx, Karl. 2008. "The Fetishism of Commodities and the Secret Thereof." In Capital, Volume 1, by Karl Marx, 47.

Merriam-Webster. 2019. "masochist." Merriam-Webster.com. Accessed March 10, 2019. https://www.merriamwebster.com/dictionary/masochist.

Rambo, Carol, and Carolyn Ellis. 1989. "Turn-Ons for Money: Interactional Strategies of the Table Dancer." Journal of Contemporary Ethnography 18: 271-298.

Schmid, Peter F. 2001. "Authenticity: The person as his or her own author. Dialogical and ethical perspectives on therapy as an encounter relationship. And beyond." In G. Wyatt (Ed.), Rogers' therapeutic conditions: Evolution, theory and practice 1, 213-228. 